\title{
Accelerating Digitisation of Biological \\ Collections: the Coimbra Herbarium case study
}

\author{
Joaquim Santos ${ }^{\ddagger}$, Fátima Sales ${ }^{\ddagger}$, Paulo Rupino ${ }^{\S}$ \\ ‡ Centre for Functional Ecology, Coimbra, Portugal \\ $\S$ CISUC, Department of Informatics Engineering, University of Coimbra, Coimbra, Portugal
}

Corresponding author: Joaquim Santos (joaquimsantos@gmail.com)

Received: 28 Jun 2019 | Published: 02 Jul 2019

Citation: Santos J, Sales F, Rupino P (2019) Accelerating Digitisation of Biological Collections: the Coimbra

Herbarium case study. Biodiversity Information Science and Standards 3: e37760.

https://doi.org/10.3897/biss.3.37760

\section{Abstract}

Hebaria are biological collections of preserved plants, algae, fungi and lichens used for scientific purposes. Fast communication and information exchange are fundamental to accelerate the investigation on biodiversity. The major world herbaria are concentrating efforts to digitise their collections and making available the information online.

Over the last decade, the Herbarium of the University of Coimbra (COI - acronym in Index Herbariorum) has made efforts to make available online the information of its plant collection of c. 800,000 specimens (http://coicatalogue.uc.pt). However, only c. $10 \%$ is processed to this date, in part due to the slowness of the methods generally used in herbaria. This work is a contribution to accelerating the digitising process, both by improving digitising procedures and by involving citizens in populating COI database.

To accomplish that, a new workflow was developed to automatically create records in the database from batches of digital images with minimum information, plus a collaborative platform was developed to allow the transcription of specimen labels from digital images in a web environment.

Creating records from the images benefits from the physical organisation of the herbarium, with specimens grouped in taxon folders. This way, when taking pictures of a set of specimens, it is possible to store them in folders with the name of the taxon. A script will 
then read the name of the folder and check in the database if each ranking of the taxon exists on the taxon tree (genus, species, infraspecific ranks), and in case it does not, it creates one, and then it creates a record based on each of the specimens inside that folder assigning a determination to it.

The collaborative application (http://coicatalogue.uc.pt/collaborative) has innovative features, such as displaying forms sequentially, revealing only one field at a time (Fig. 1). But the most differentiating feature is probably the process of validation for submitted values. Registered users are included under a category, according to their contribution history. Contributors can be upgraded to the next level when they submit a certain number of validated fields. Therefore, there is a progression based on proficiency, allowing users to become familiar with the specimen information system as they use the platform and, simultaneously, it attributes a confidence level to users. This can be used to validate data, assigning a confidence value to a submission, based on user status (points system). Validation of values submitted by users is obtained when the sum of points for a concurrent value meets a threshold, so a single answer from an expert user could be enough to get validation but would require five basic users submitting the same value to be accepted (Table 1).

Table 1.

Collaborative application: user categories and roles.

\begin{tabular}{|l|l|l|l|l|}
\hline Role & Category & Description & $\begin{array}{l}\text { Accepted } \\
\text { submissions } \\
\text { required }\end{array}$ & $\begin{array}{l}\text { Points attributed to } \\
\text { each submission }\end{array}$ \\
\hline CONTRIBUTOR & Basic & $\begin{array}{l}\text { First time user. Fields displayed are } \\
\text { restricted. }\end{array}$ & 0 & 10 \\
\cline { 2 - 3 } & Beginner & $\begin{array}{l}\text { More fields are displayed, but some } \\
\text { are restricted. }\end{array}$ & 10 & 20 \\
\hline & Competent & $\begin{array}{l}\text { More fields are displayed, but some } \\
\text { are restricted. }\end{array}$ & 50 & 30 \\
\hline & Advanced & $\begin{array}{l}\text { More fields are displayed, but some } \\
\text { are restricted. }\end{array}$ & 100 & 40 \\
\hline & Expert & Can submit all fields. & 50 \\
\hline ADMINISTRATOR & Administrator & $\begin{array}{l}\text { Can perform all tasks above, data } \\
\text { management (submission approval). }\end{array}$ & - & 50 \\
\hline & Root & $\begin{array}{l}\text { Can perform all tasks above, } \\
\text { administrator management, } \\
\text { specimen management. }\end{array}$ & -50 \\
\hline
\end{tabular}

Although collateral, there is a major, and unique, advantage to this project. The collaborative application can be used as a tool to make corrections to the herbarium database, easily and directly online. This quickly improves the database as such effortless procedure increases this kind of contributions. 


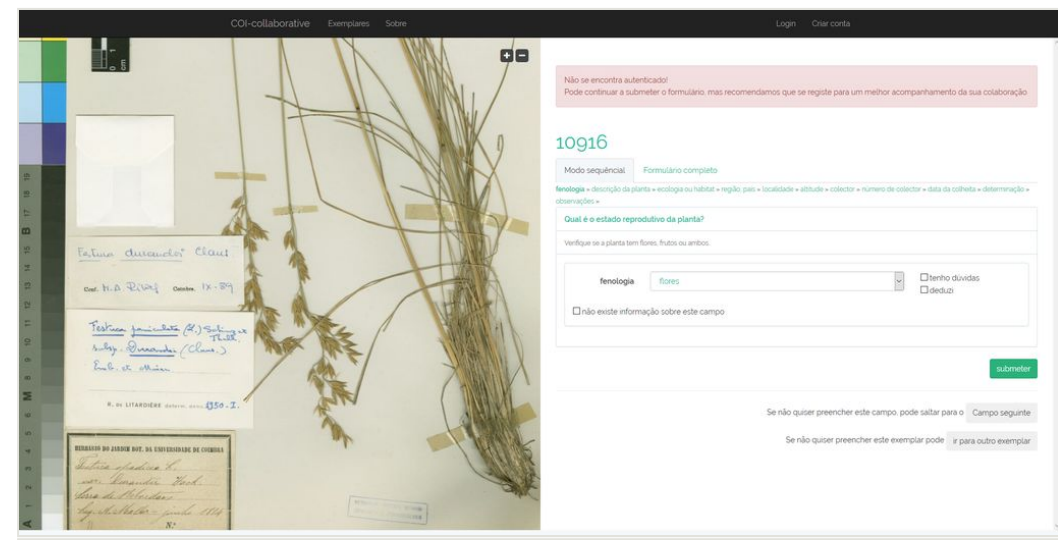

Figure 1.

Collaborative application in specimen view, showing the image and the form side-by-side.

\section{Keywords}

collaborative applications, digitising herbaria, automate databasing processes, specimen annotation, community data editing

\section{Presenting author}

Joaquim Santos

\section{Presented at}

Biodiversity_Next 2019

\section{Hosting institution}

Herbarium of the University of Coimbra 